\title{
Path Analysis on the Factors Associated with Consistent Use of Female Condom among Female Sex Workers in Surakarta
}

\author{
Rizka Ayu Setyani'), Ari Natalia Probandari²), Argyo Demartoto) \\ ${ }^{1)}$ School of Midwivery, Universitas Respati, Yogyakarta \\ 2) Faculty of Medicine, Universitas Sebelas Maret \\ 3)Faculty of Social and Political Sciences, Universitas Sebelas Maret
}

\begin{abstract}
Background:Female condom is an alternative method to prevent HIV/ AIDS transmission. However, its utilization is low and scanty among female sex workers. It is important to have knowledge on the factors that determine female condom use. This study aimed to determine the factors associated with the acceptance and use of female condom among female sex workers in Surakarta. Subjects and Method: It was an analytic and observational study using case control design.The study was conducted at a prostitution area in Surakarta, Central Java, from August to September 2016. A total of 230 female sex workers consisting of 110 female sex workers who used female condoms and 120 female sex workers who did not use female condoms, was selected purposively in this study.The dependent variables were acceptance and use of female condom. The independent variables were sex partner support, peer educator support, and pimp support. The data were collected by a set of questionnaire and analyzed by path analysis model.

Results: Acceptance of female condom was associated with its use among female sex workers $(b=$ 0.30; $\mathrm{p}<0.001)$.Peer educatorsupport was associated with acceptance of female condom $(\mathrm{b}=$ 0.06; $\mathrm{p}<0.001)$. Peer educator support $(\mathrm{b}=0.03$; nilai $\mathrm{p}=0.012)$ and sex partner support $(\mathrm{b}=$ $0.05 ; \mathrm{p}=0.042)$. The association between acceptance of female condom and pimp support was not statistically significant $(\mathrm{p}=0.133)$.

Conclusion: Peer educator support and sex partner support have direct association with both acceptance and use of female condom among female sex workers.
\end{abstract}

Keywords: path analysis, support, sex partner, peer educator, consistant use, female condom, female sex workers

\section{Correspondence:}

Rizka Ayu Setyani. School of Midwivery, Universitas Respati, Yogyakarta. Email: bidanrizkaayusetyani@gmail.com

\section{BACKGROUND}

HIV AIDS still become a global health problem. In 2014, Central Java ranked $5^{\text {th }}$ in HIV / AIDS cases after DKI Jakarta, East Java, West Java, and Papua, while Surakarta City had the second highest HIV case in Central Java after Semarang (AIDS Prevention Commission of Central Java, 2015). In October 2005 to December 2015 there were 399 female sex workers in Surakarta. There were 82 cases of female sex workers with HIV positive and 48 cases had entered the AIDS stage. This is caused by the lack of awareness of HIV transmission prevention (AIDS Prevention Commission of Surakarta, 2015). According to Integrated Biological and Behavior Survey in 2013 in Indonesia, direct female sex workers who always used condoms during sexual intercourse by $45 \%$, and indirect female sex workers by $36 \%$, whereas the regulation on HIV / AIDS has been stated in Regulation of the Minister of Health of Indonesia Number 21 of 2013, circular letter from the minister of health of Indonesia Number 129 of 2013, Central Java 
Journal of Health Promotion and Behavior (2016), 1(2): 121-127

https://doi.org/10.26911/thejhpb.2016.01.02.07

Provincial Regulation Number 5 of 2009, and Surakarta Regional Regulation Number 12 of 2014. Condoms are not only used by men, women can also use condoms. Thus, female sex workers do not depend on customers in using condoms because not all customers want to use condoms (Budiono, 2012; Ezire et al., 2013; Aryani et al., 2015; Mathenjwa et al., 2012; Purnamawati, 2013).

According to the theory of PRECEDE PROCEED by Lawrence and Green, behavior change is influenced by reinforcing factors, namely the support factor. Previous study by Moore et al (2015); Ouzouni and Nakakis (2012); Tafaune and Monareng (2016) stated that the acceptance and usage of condoms are consistently influenced by good support. This study aimed to explain the effect of customer, pimps, and peer educators support on the consistency of female condom use in female sex workers.

\footnotetext{
SUBJECTS AND METHOD

This quantitative study used an analytic observational design with a case control design. The study was conducted in Surakarta on August to September 2016. Sampling was done by purposive sampling technique. Subjects in the case group were 110 female sex workers and in the control group were 120 female sex workers taken from different localization to avoid contamination bias. The instrument used for measuring the acceptance and use of female condoms variable was questionnaires, which previously had been carried out face validity and the contents were then tested by Product Moment of Pearson's correlation technique. Reliability was done on 30 female sex workers behind Tirtonadi Terminal Surakarta. Reliability test technique used Cronbach Alpha.
}

Data entry was done by blinding and double entry via EpiData 3.1. Path analysis used IBM SPSS AMOS 20 to examine the association between exogenous variables (customer, pimp, and peer educator support) with endogenous variables (acceptance of female sex workers on female condoms, and female condom use in sex workers).

RESULTS
The results of this study discussed the
characteristics of the sample of the study
and the results of path analysis (path
analysis). Table 1 explains the average age
of female sex workers in the case group was
36.14 years and 31.83 years in the control
group. The majority of female sex workers
in the case group had a junior high school
education of $44.5 \%$ and $48.3 \%$ in the
control group. According to the results of
the study, $79.1 \%$ of the female sex workers
in the case group and $76.7 \%$ of the female
sex workers of control group did not know
the previous female condom and $85 \%$ of
female sex workers in each group had never
tried using it. Viewed from income charac-
teristics per day, $50 \%$ of female sex workers
in the case group and $45 \%$ of female sex
workers in the control group had a daily
income of Rp 10o,ooo to Rp 500, ooo.
Path analysis was used to understand
the associationn among customer, pimp,
and peer educator support on the consist-
ency of female condom used with the
acceptance as a mediator. The analysis
model of the completion path is in Figure 1.
The result of the degree of freedom
(df) is 2 which means over identified or
path analysis can be done. Figure 2 shows
the structural model after estimation using
IBM SPSS AMOS 20.

RESULTS
The results of this study discussed the
characteristics of the sample of the study and the results of path analysis (path analysis). Table 1 explains the average age of female sex workers in the case group was 36.14 years and 31.83 years in the control group. The majority of female sex workers in the case group had a junior high school education of $44.5 \%$ and $48.3 \%$ in the control group. According to the results of the study, $79.1 \%$ of the female sex workers in the case group and $76.7 \%$ of the female sex workers of control group did not know the previous female condom and $85 \%$ of female sex workers in each group had never tried using it. Viewed from income characteristics per day, $50 \%$ of female sex workers in the case group and $45 \%$ of female sex workers in the control group had a daily Path analysis was used to understand the associationn among customer, pimp, and peer educator support on the consistency of female condom used with the acceptance as a mediator. The analysis model of the completion path is in Figure 1. (df) is 2 which means over identified or path analysis can be done. Figure 2 shows the structural model after estimation using 
Journal of Health Promotion and Behavior (2016), 1(2): 121-127

https://doi.org/10.26911/thejhpb.2016.01.02.07

Table 1. Characteristics of the sample of the study

\begin{tabular}{|c|c|c|c|c|}
\hline \multirow{2}{*}{ Characteristic } & \multicolumn{2}{|c|}{ Case Group $(n=110)$} & \multicolumn{2}{|c|}{ Control Group $(n=120)$} \\
\hline & Mean \pm SD & n (\%) & Mean \pm SD & n (\%) \\
\hline Age of FSW & $36.14 \pm 9.38$ & & $31.83 \pm 9.27$ & \\
\hline Education of FSW & & & & \\
\hline Uneducated & & o (o\%) & & o (o\%) \\
\hline Elementary school & & $41(37.3 \%)$ & & $41(34.2 \%)$ \\
\hline Junior High School & & $49(44.5 \%)$ & & $58(48.3 \%)$ \\
\hline High School & & $19(17.3 \%)$ & & $21(17.5 \%)$ \\
\hline Diploma & & $1(0.9 \%)$ & & o (o\%) \\
\hline Bachelor & & $\mathrm{o}(0 \%)$ & & o (o\%) \\
\hline \multicolumn{5}{|l|}{ Previous Knowledge } \\
\hline Know & & $23(20.9 \%)$ & & $28(23.3 \%)$ \\
\hline Do not-know & & $87(79.1 \%)$ & & $92(76.7 \%)$ \\
\hline \multicolumn{5}{|l|}{ FSW experience } \\
\hline Already & & $16(14.5 \%)$ & & $18(15 \%)$ \\
\hline Not yet & & $94(85.5 \%)$ & & $102(85 \%)$ \\
\hline \multicolumn{5}{|l|}{ FSW daily income } \\
\hline$<\operatorname{Rp} 100,000$ & & $37(33.6 \%)$ & & $42(35 \%)$ \\
\hline $\operatorname{Rp} 100,000$ to $\operatorname{Rp} 500,000$ & & $55(50 \%)$ & & $54(45 \%)$ \\
\hline Rp 500,000 to Rp 1,000000 & & $13(11.8 \%)$ & & $21(17.5 \%)$ \\
\hline$\geq \mathrm{Rp} 1,000,000$ & & $5(4.6 \%)$ & & $3(2.5 \%)$ \\
\hline
\end{tabular}

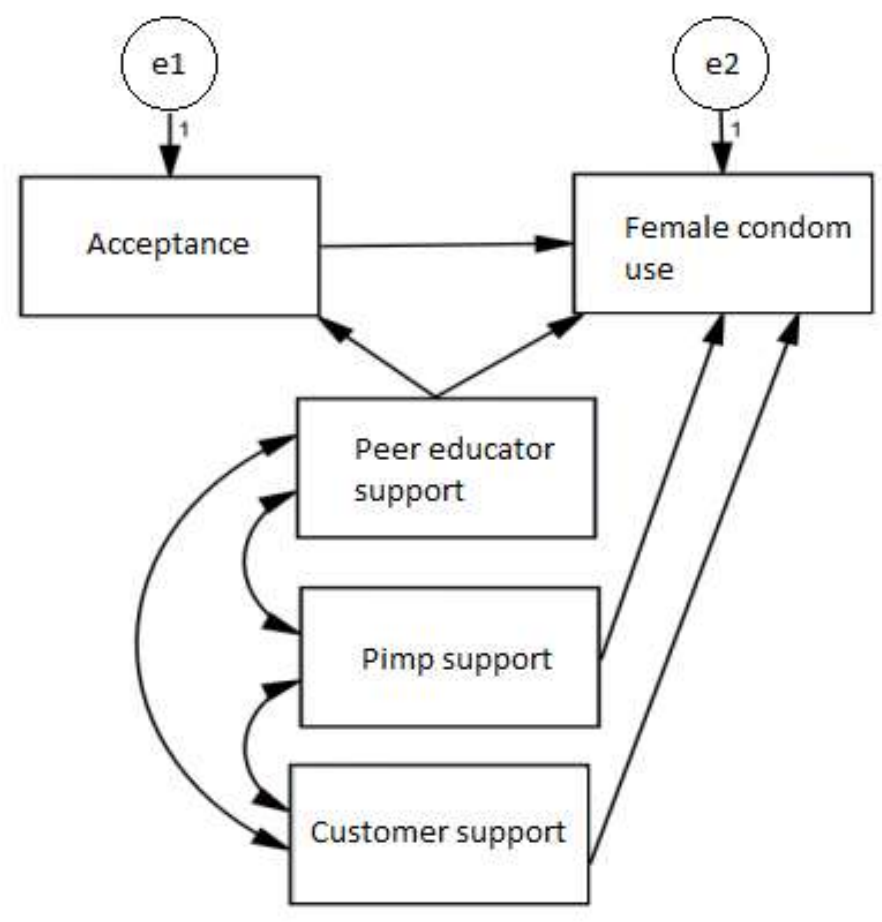

Figure 1. Structural Model of Path Analysis 


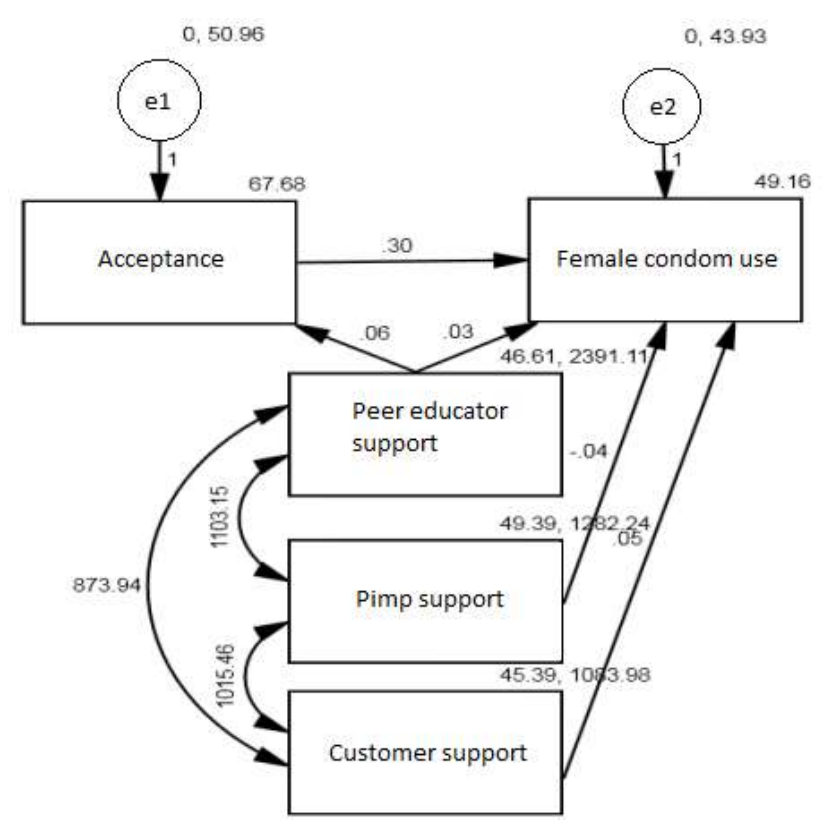

Figure 2. Structural model of path analysis with estimation

Table 2. The Result of Path Analysis

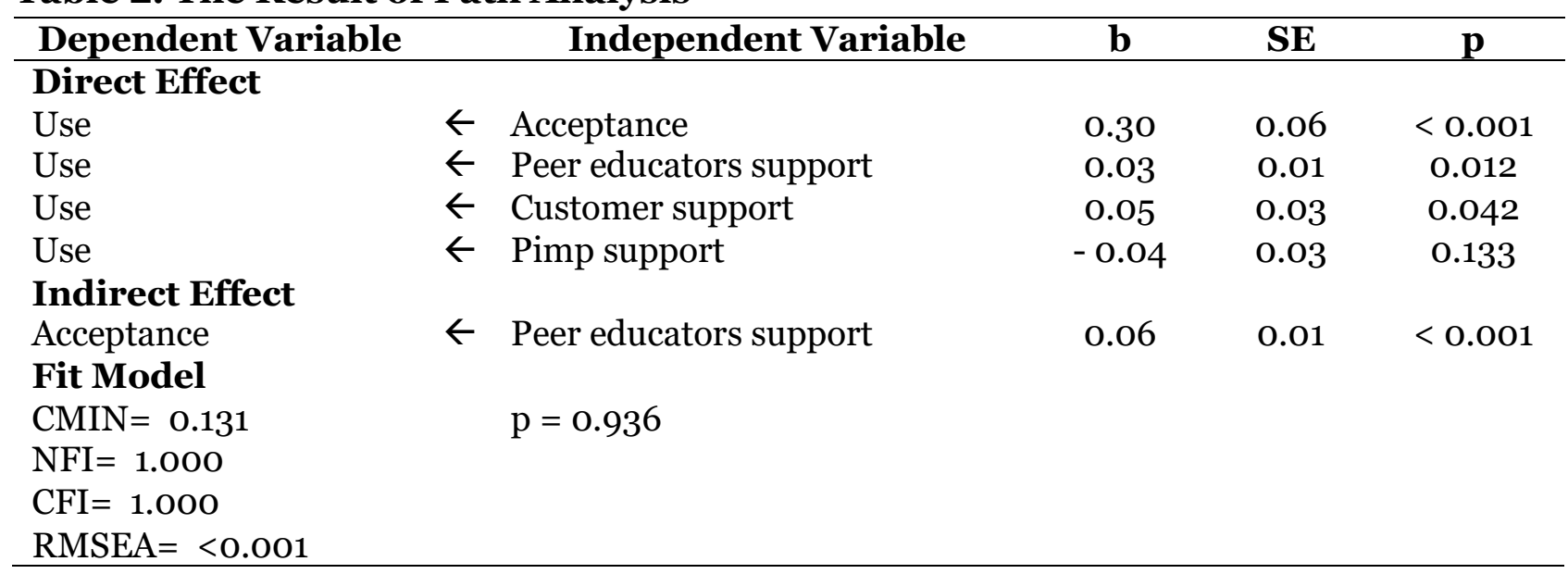

Table 2 shows the suitability indicators of the path analysis model with the goodness of fit measure that the CMIN fit index results were 0.131 with a value of $\mathrm{p}=0.936$ $>0.05 ; \mathrm{NFI}=1,000>0.90 ; \mathrm{CFI}=1,000$ $>0.90$; RMSEA $=0,000<0.05$.

Table 2 showed that there was a positive association between acceptance and the consistency of female condom use $(b=0.30 ; p<0.001)$.

There was a direct positive association between peer educators support and the consistency of female condom use $(b=$ o.03; $\mathrm{p}=0.012$ ).

There was a direct positive association between customer support and the consistency of female condom use $(b=0.05 ; p=$ 0.042).

There was a positive direct association between peer educator support and acceptance of FSW to female condom, $(b=0.06$; $\mathrm{p}<0.001)$.

There was no association between the support of pimps and the consistency of female condom use $(p=0.133)$. 


\section{DISCUSSION}

Based on the results of path analysis in table 2, it is proven that the acceptance of female sex workers on female condoms is associated to the consistency of the use of female condoms. The results of the study by Ouzouni and Nakakis (2012) stated that acceptance is a person's tendency to act. Therefore, in increasing the consistency of female condom use, AIDS Eradication Commission needs to provide assistance. This effort can be carried out through the collaboration of all parties. Mentoring activities include the provision of routine socialization, simulation, and support until a good reception is formed. If female sex workers have felt and accepted that female condoms are beneficial, they will automatically have the awareness to use it consistently. In this assistance effort, AIDS Eradication Commission needs to question what are the problems associated to the acceptance and use of female condoms directly to users, so that the program's follow-up plan can be targeted according to the existing problems.

Similarly, the support of the peer educator was directly associated to female sex workers acceptance of female condoms and the consistency of female condom use. According to the theory of Budiman et al (2014), the influence of others, such as peers, can influence one's acceptance of attitudes.

Support from peer educators can be a force to encourage and influence peers and can be a good example of condom use, STI screening, and HIV testing (Gessang, 2009). Previous study conducted by Agustini and Arsani (2013); Bagnal et al (2015); Chersich et al (2015); Follona et al (2014); Ibrahim and Sidani (2014); Kerrigan et al (2013); Medley et al (2009); Ota et al (2011); and Wang et al (2013), stated that peer educator support is effective for improving HIV prevention attitudes and practices because they are carried out by peer educators who are members of the community itself. Peer educator is someone who emotionally has closeness to members of his community, in this case are female sex workers. However, currently there is only one peer educator who is an active sex worker in Surakarta, making it less effective. According to the Surakarta HIV and AIDS Strategic Plan for 2016-2020 there are prospective peer educator training programs and strengthening selected peer educators. The addition and strengthening of peer educator female sex workers is expected to increase the acceptance and consistency of female condom use in female sex workers.

The results of this study also prove that customer support was associated to the consistency of female condom use. Female sex workers in this study said that old customers are more supportive than new customers. Customer support is one factor that makes female sex workers can receive and use female condoms. It is in accordance with the results of study from Budiono (2012); and Moore et al (2015) which stated that the perception or support of customers about conducting safe sex is a factor that influences condom use.

Therefore, the socialization carried out by the AIDS Eradication Commission regarding HIV prevention should not only for female sex workers but also for old and prospective customers. So, female sex workers and customers get the same understanding and acceptance of consistent female condom use.

The pimp's support has nothing to do with the consistency of female condom use. The presence of female condoms helps pimps to promote female sex workers because they do not have to encourage customers to use male condoms. However, 
Journal of Health Promotion and Behavior (2016), 1(2): 121-127

https://doi.org/10.26911/thejhpb.2016.01.02.07

related to using it consistently or not, it depends on female sex workers themselves. According to the results of a study by Budiono (2012), one of the factors that influence the practice of condom use is the support of pimps. However, for female sex workers, pimps are only the boss where there are more customers, the income will increase. Cooperation between AIDS Eradication Commission and pimps of female sex workers is important. Pimps play a role as citizens concerned about AIDS who are tasked with informing female condom use informally to female sex workers. The AIDS Eradication Commission can approach the pimps by providing information on the use of female condoms so that synergy among AIDS Eradication Commission, pimps, and female sex workers is expected.

The peer educator's support and customer's support directly affect the acceptance and consistency of female condom use in female sex workers. In contrast, pimp support and acceptance are not associated to the consistency of female condom use in female sex workers.

$\frac{\text { REFERENCE }}{\text { Agustini NNM, Arsani NLKA (2013). Re- }}$ maja sehat melalui pelayanan kesehatan peduli remaja di tingkat puskesmas. KEMAS. 9(1): 66-73.

Aryani D, Mardiana, Ningrum DNA (2015) Perilaku pencegahan infeksi menular seksual pada wanita pekerja seksual Kabupaten Tegal. KEMAS 10(2): 160168.

Bagnall AM, South J, Hulme C, Woodal J, Collier KV, Raine G, Kinsella K (2015). A systematic review of the effectiveness and cost effectiveness of peer education and peer support in prisons. BMC Public Health 15(290): 1-30.
Budiman, Riyanto A (2014). Kapita selekta kuesioner: Pengetahuan dan sikap dalam penelitian kesehatan. Jakarta: Salemba Medika.

Budiono I (2012). Konsistensi Penggunaan Kondom oleh Wanita Pekerja Seks/ Pelanggannya. KEMAS 7(2): 89-94.

Chersich MF, Luchters S, Ntaganira I, Gerbase A, Lo YR, Scorgie F, Steen R (2013). Priority Interventions to Reduce HIV Transmission in Sex Work Settings in Sub-Saharan Africa and Delivery of These Services. Journal of the International AIDS Society. 16(17980): 1-8.

Ezire O, Oluigbo O, Archibong V, Ifeanyi O, Anyanti J (2013). Barriers to repeated use of female condom among women and men of reproductive age in Nigeria. Journal of AIDS and HIV Research 5(6): 206-213.

Follona W, Raksanagara AS, Purwara BH (2014). Perbedaan pendidikan kelompok sebaya tentang pendewasaan usia perkawinan di perkotaan dan perdesaan. Kesmas, Jurnal Kesehatan Masyarakat Nasional 9(2): 157-163.

Gessang (2009). Mengenal lebih dekat peer educator (PE), ww.gessang.org. Retrieved May 6, 2016.

Green LW, Kreuter MW (1992). CDC's planned approach to community health as an application of PRECEDE and an Inspiration for PROCEED. Journal of Health Education. 23(3): 140-147.

Green LW, Kreuter MW (1999). Health promotion planning: An educational and ecological approach. Mountain View, CA: Mayfield.

Ibrahim S, Sidani S (2014). Community based HIV prevention intervention in developing countries: A systematic review. Hindawi Publishing Corporation Advances in Nursing: 1-11. 
Kementerian Kesehatan Republik Indonesia (2013). Survey Terpadu Biologis Perilaku pada Kelompok Berisiko Tahun 2013. Jakarta: Kemenkes RI.

Kerrigan DL, Fonner VA, Stromdahl S, Kennedy CE (2013). Community empowerment among female sex workers is an effective HIV prevention intervention: A systematic review of the peer-reviewed evidence from lowand middle-income countries. AIDS Behav. 17: 1926-1940.

Komisi Penanggulangan AIDS Kota Surakarta (2015). Kasus HIV dan AIDS Desember 2015 di Kota Surakarta. Surakarta: KPA Kota Surakarta

Komisi Penanggulangan AIDS Kota Surakarta (2016). Rencana strategis penanggulangan HIV dan AIDS Kota Surakarta Tahun 2016-2020. Surakarta: KPA Kota Surakarta.

Komisi Penanggulangan AIDS Provinsi Jawa Tengah (2014). Kondisi HIV dan AIDS di Jawa Tengah. Semarang: KPA Provinsi Jateng.

Mathenjwa T, Maharaj P (2012). Female condoms give women greater control: A qualitative assessment of the experiences of commercial sex workers in Swaziland. The European Journal of Contraception and Reproductive Health Care. 17: 383-392.

Medley A, Kennedy C, Reilly KO, Sweat M (2009). Effectiveness of peer education interventions for HIV prevention in developing countries: A systematic review and meta-analysis. AIDS Education and Prevention. 21(3): 181206.

Moore L, Beksinska M, Rumphs A, Festin A, Gollub EL (2015). Knowledge, attitudes, practices and behaviors associated with female condoms in developing countries: A scoping review.
Journal of Contraception. (6): 125142.

Ota E, Wariki WMV, Mori R, Hori N, Shibuya $K$ (2011). Behavioral interventions to reduce HIV transmission among sex workers and their clients in high-income countries. Cochrane Database of Systematic Reviews. 12.

Ouzouni C, Nakakis K (2012). HIV/ AIDS Knowledge, Attitudes and Behaviours of Student Nurses. Health Science Journal 6(1): 129-150.

Peraturan Daerah Jawa Tengah Nomor 5 Tahun 2009 Tentang Penanggulangan HIV dan AIDS.

Peraturan Daerah Kota Surakarta Nomor 12 Tahun 2014 Tentang Pencegahan dan Penanggulangan HIV dan AIDS.

Peraturan Menteri Kesehatan Republik Indonesia Nomor 21 Tahun 2013 Tentang Penanggulangan HIV dan AIDS.

Peraturan Pemerintah Nomor 39 Tahun 1995 Tentang Penelitian dan Pengembangan Kesehatan.

Purnamawati D (2013) Perilaku pencegahan penyakit menular seksual di kalangan wanita pekerja seksual langsung. Kesmas, Jurnal Kesehatan Masyarakat Nasional. 7(11): 514-521.

Surat Edaran Menteri Kesehatan Republik Indonesia Nomor 129 Tahun 2013 Tentang Pelaksanaan Pengendalian HIV AIDS dan IMS.

Tafaune BM, Monareng LV (2016). Perception and attitude of healthcare workers towards the use of a female condom in Gaborone, Botswana. Elsevier Health Sa Gesondhe Id. 162-170.

Wang Y, Liao S, Jiang J, Weeks MR, Nie L, Li J, He B (2013). Who are the preferential targets for intervention programs related to the female condom among sex workers in Southern China?. AIDS Education and Prevention. 